\title{
Shear strength of reinforced concrete circular cross-section beams
}

\section{Resistência à força cortante de vigas de concreto armado com seção transversal circular}

P. W. G. N. TEIXEIRA a pedro-wellington@uol.com.br

C. E. M. MAFFEI ${ }^{b}$ maffei@maffeiengenharia.com.br

M. C. GUAZZELLI ${ }^{\circ}$ mcg@maffeiengenharia.com.br

\begin{abstract}
A proposed adequation of NBR 6118 , Item 7.4, related to shear strength of reinforced concrete beams is presented with aims to application on circular cross-section. The actual expressions are most suitable to rectangular cross-section and some misleading occurs when applied to circular sections at determination of $\mathrm{VRd} 2, \mathrm{Vc}$ and $\mathrm{Vsw}$, as consequence of bw (beam width) and $\mathrm{d}$ (effective depth) definitions as well as the real effectiveness of circular stirrups. The proposed adequation is based on extensive bibliographic review and practical experience with a great number of infrastructure elements, such as anchored retaining pile walls, where the use of circular reinforced concrete members is frequent.
\end{abstract}

Keywords: shear; reinforced concrete; circular section; retaining walls.

\section{Resumo}

Neste trabalho apresenta-se proposta de adequação das expressões da ABNT NBR 6118 referentes à verificação da resistência à força cortante de vigas de concreto armado para o caso de seção circular. As expressões atuais são mais adequadas à seção retangular e apresentam algumas dúvidas quando se utilizam para seções circulares, no cálculo de VRd2, Vc e Vsw, devido às definições de bw (largura da viga) e d (altura útil da viga) e também à eficiência de estribos circulares. A adequação proposta é baseada em extensa revisão bibliográfica e em experiências práticas obtidas com grande número de projetos de elementos de infraestrutura, tais como paredes de contenção com estacas atirantadas, nos quais o uso de elementos de seção circular sujeitos a altos valores de forças cortantes é bastante frequente.

Palavras-chave: força cortante; concreto armado; seção circular; paredes de contenção.

a Universidade de São Paulo, Escola Politécnica, Departamento de Estruturas e Geotécnica, pedro-wellington@uol.com.br, Av. Prof. Luciano Gualberto - Travessa 3 no 380 - Cidade Universitária - Butantã, CEP 05.508-010, São Paulo-SP, Brasil;

Universidade de São Paulo, Escola Politécnica, Departamento de Estruturas e Geotécnica, maffei@maffeiengenharia.com.br, Av. Prof. Luciano Gualberto - Travessa 3 no 380 - Cidade Universitária - Butantã, CEP 05.508-010, São Paulo-SP, Brasil; Maffei Engenharia, mcg@maffeiengenharia.com.br, Rua Moura Brasil, 183. Butantã. São Paulo, SP - Brasil. 


\section{Introduction}

Reinforced concrete circular cross-section beams are often used in infrastructure works, such as retaining structures for excavations (Figure 1). Utilization of circular cross-section beams for shallow tunnels has also been verified in recent projects.(Maffei [8], [9]) (Figure 2).

The determination of shear strength of these elements on Ultimate Limit States must be made by the expression given on item 17.4 of NBR 6118 [1]. However, the application of the Brazilian Standard expression for circular cross-section beams presents some problems, such as: (a) the applicability of the expression used for the determination of $\mathrm{V}_{\mathrm{Rd} 2}$, the shear strength design related to the concrete failure by diagonal compression; (b) the definition of the value of $b_{w}$ for the calculation of $V_{c}$, the parcel of shear force resisted for complementary mechanisms to truss; (c) doubts related to the efficiency of circular stirups in shear strength when determining $V_{s w}$, the portion of the shear force resisted by shear reinforcement.

Attempts to cover this subject are found in literature [2], [3], [4], [5], [6]. Jensen et al. [2], present the test results of sixteen circular beams. The tested beams had a diameter of $25 \mathrm{~cm}$ and were reinforced with different longitudinal and transverse arrangements (Figure 3). The cited authors used the American Standard AASHTO LFRD Bridge Design Specifications, 2007 [11],to estimate the resistance of the tested beams. The presented results suggests that the application of the expressions of AASHTO (2007) may lead to safe values of shear strength of reinforced concrete circular cross-section beams as shown in the item 4 of this study. Merta [4], presents analytical model for determining the shear strength of reinforced concrete beams of circular section. For determining the value of $V_{c}$, the above author presents expressions in which the influence of the main variables were empirically determined based on the results of 44 testing circular beams reinforced only with longitudinal rebars, ie, without the use of stirrups. For the calculation of $\mathrm{V}_{\mathrm{sw}}$, Merta [4] proposes model that takes into account the curved stirrup sand divides the contribution of the

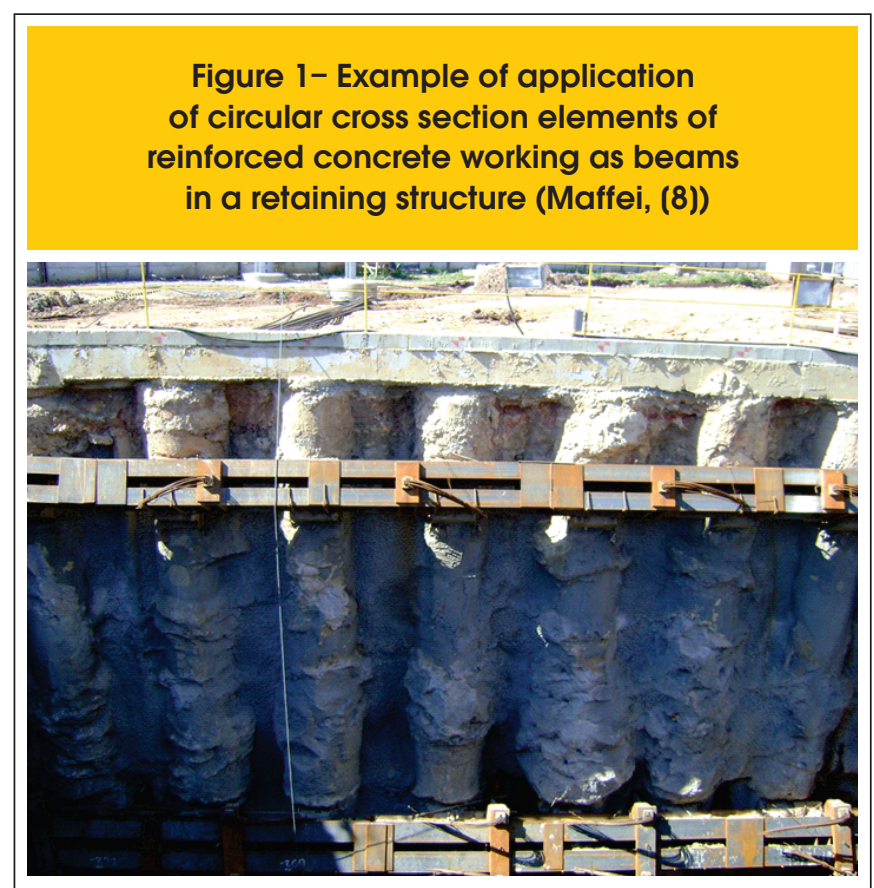

reinforcement into two parts: the vertical component of force in the stirrup crossing this hear crack and over an additional portion due to radial forces that a rise due to the adhesion between the steel and concrete.

A useful concept introduced by Merta \& Kolbitsch [5] and Li [3] is the effective area $\left(A_{e f}\right)$ for shear force, also called "shear area" in one of the works.

A similar concept is used by the Brazilian code of steel structures, NBR8800 (2010). According to this standard, the effective area in this context would be that obtained by the ratio $\mathrm{V} / \zeta_{\text {máx }}$, where Vis the shear force in the section and $\zeta_{\text {max }}$ is the maximum shear stress in the section obtained with Jourávski expression[7]. The

Figure 2 - Example of application of reinforced concrete circular cross section elements working as beams in a shallow tunnel (Maffei, (9)): (a) details of the reinforcement; (b) concluded beams
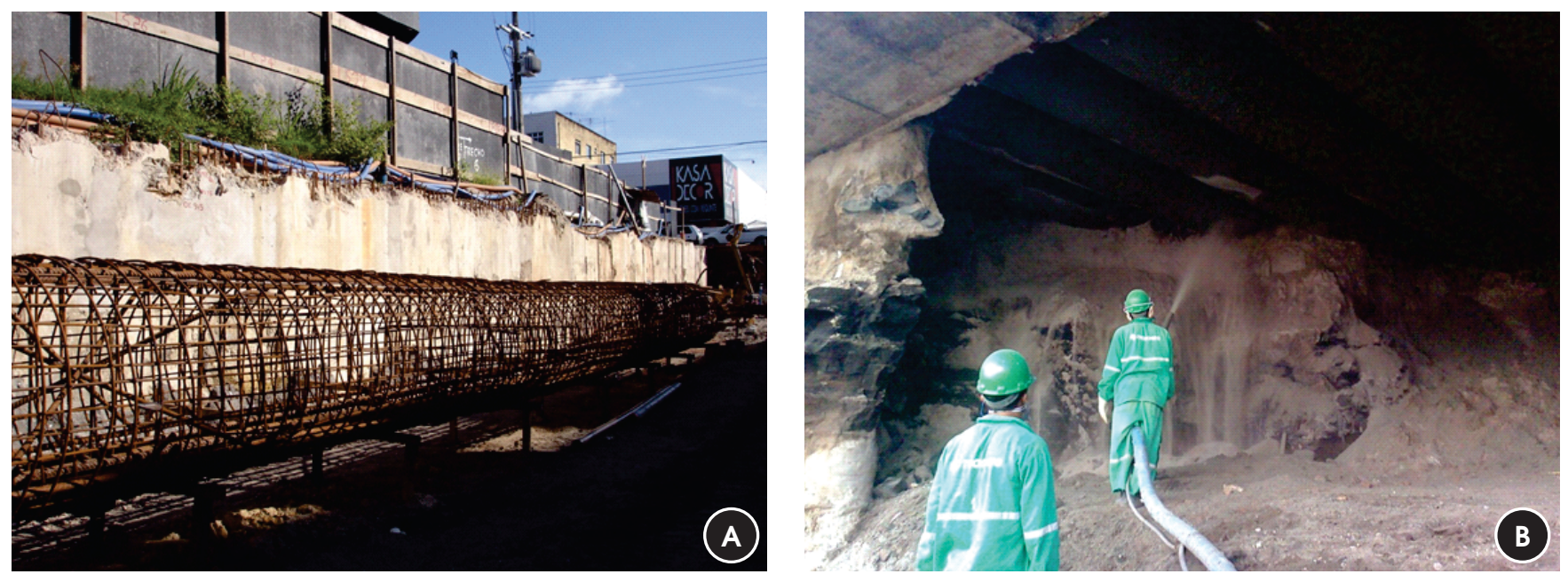
application of Jourávski expression for circular section scan provide a good indication of how the shear stresses derived from the shear force are distributed by section. An alternative procedure for application of this expression can be based on the division of the circular section in ellipses with the major axis parallel to the direction of the shear force, and distributing the shear force among each of these ellipses. It is a simplified procedure that allows visualization of the orientation of the tangential stresses in the cross section

Figure 3 - Reproduction of Figure 3 of Jensen et al. (2)
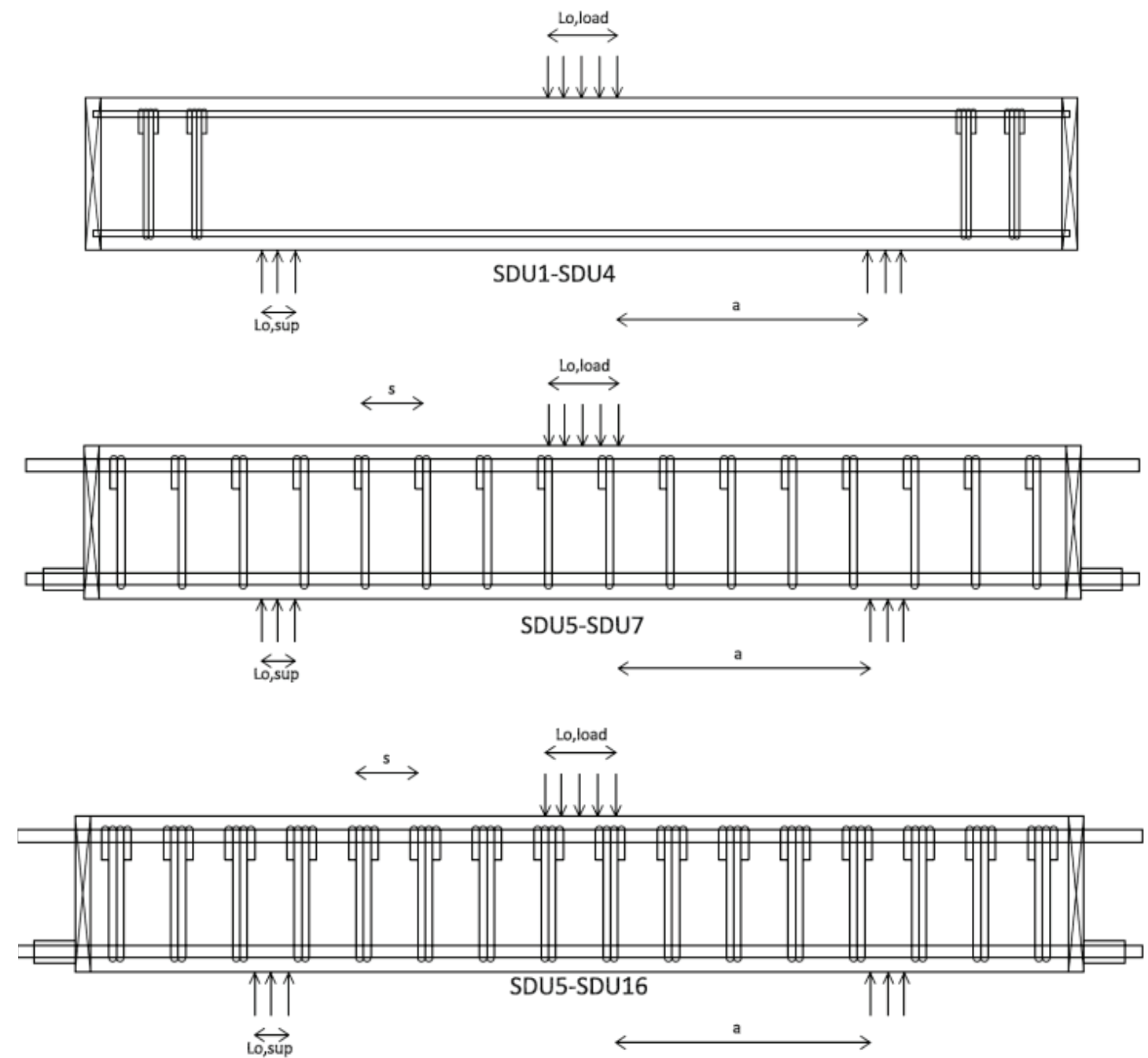

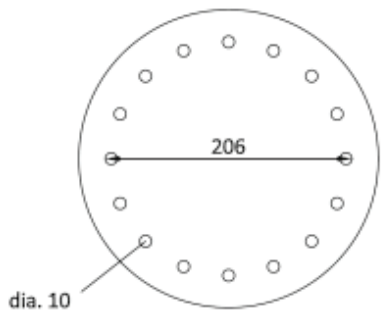

SDU1-SDU4

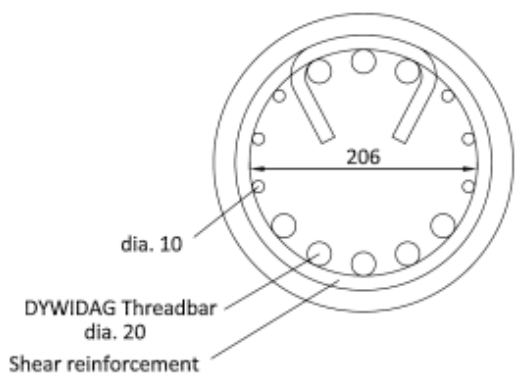

SDU5-SDU16 
Figure 4 - Simplified procedure for determining the tangential stresses at all points of a circular cross section with use of Jourávski formula: divide the shear force V between " $n$ " ellipses and apply the Jourávski expression to each of these ellipses, taking as the thickness the measure perpendicular to the axis of said elliptical figure

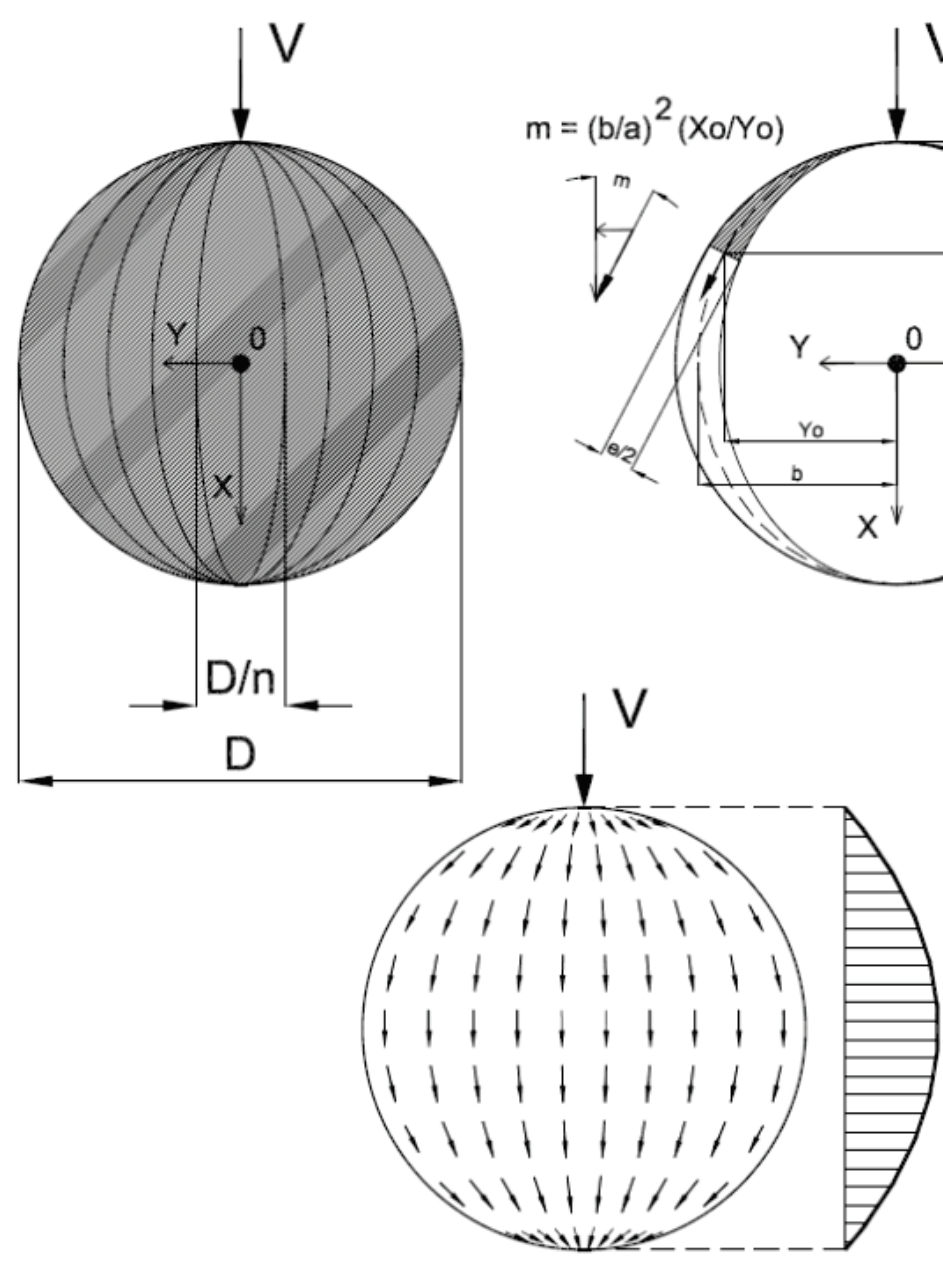

(Figure 4). According to this procedure $\zeta_{\text {max }}=1.33 \mathrm{~V} / \mathrm{A}$. However, the exact value of the maximum stress is given by the Theory of Elasticity and depends on Poisson's ratio of the material[10]. For concrete, withv $=0.2, \zeta_{\text {máx }}=1.42 \mathrm{~V} / \mathrm{A}$.

In the case of circular section of reinforced concrete, the effective area is defined by these authors in a different way, considering only one part of the concrete section. Thus, the effective area would be the area of the segment of circular cross-section corresponding to the effective depth " $d$ ", where " $d$ " is the distance between the more compressed point of the cross section due to the bending moment, and the center of gravity of the longitudinal tensile bars (Figure 4). The value of " $d$ " should be determined after knowledge of the section neutral axis by identifying which longitudinal bars were in fact tensioned; at this manner, there is need for iterative calculation. For usual dimensions and uniform arrangements of reinforcement however, according to [5], $A_{e f}=0.7 A_{g}$, where $A_{g}$ is the gross area of the circular cross section.

Using the concept of effective area, the difficulty of determining the value $b_{w}$ to be used inexpression of NBR6118 can be eliminated substituting the product $b_{w} d$ that appears in the expressions of $V_{c}$ and of $\mathrm{V}_{\mathrm{Rd} 2}$ by the effective area.

However, besides the fact that this substitution would need to have a higher basement, theoretical and or experimental, this is not the only problem to be solved for the application of the expressions of Item 4.17 of NBR 6118 to circular sections. These aspects will be discussed in the following items.

\section{Aspects of design}

\subsection{Calculation of $V_{R d 2}$}

Jensen et al. [2], presents the expression of AASHTO (2007), given by, for determining the shear resistance design related to the 
concrete failure by diagonal compression. In this expression, the mentioned authors say that $b_{v}=D$ and $d_{v}=0.72 D$ should be used for circular section. Applying this expression to the beams tested by these authors, we have:

$$
\mathrm{V}_{\mathrm{rd} 2}=0.25 \times 25 \mathrm{~cm} \times 0.72 \times 25 \mathrm{~cm} \times 3.17 \mathrm{kN} / \mathrm{cm}^{2}=356 \mathrm{kN}
$$

If it were used the concept of effective area, it would still be obtained lower value which probably indicates that the use of effective area must be associated with other parameters. The calculations would be as follows:

$$
\mathrm{V}_{\mathrm{rd} 2}=0.25 \times 0.7 \times \frac{\pi \times 25^{2}}{4} \times 3.17=272 \mathrm{kN}
$$

Among the sixteen tested beams, at least eight of them reached greater values than $356 \mathrm{kN}$, and one of the beams showed rupture with $\mathrm{V}_{\mathrm{u}, \exp }=479 \mathrm{kN}$ - difference of $34 \%$. The authors have not commented on this aspect in the article but it is interesting to discuss this result. Among these beams that have reached the ultimate load value that exceeds the crushing strength of the struts, the difference occurred only in the transverse reinforcement, and all of them had heavy longitudinal reinforcement, with geometric rate $\rho=6.4 \%$. The beam that showed greater strength had shear reinforcement consisting of double stirrups of $12 \mathrm{~mm}$ with spacing of $10 \mathrm{~cm}$. Referring to the diameter $(D=25 \mathrm{~cm})$, this provides a shear reinforcement geometric rate of approximately $4 \times 1.25 \mathrm{~cm}^{2} /$ $(25 \mathrm{~cm} \times 10 \mathrm{~cm})=2 \%$, which is a high value for a beam with $f_{c k}$ on the order of $30 \mathrm{MPa}$. Considering the current parameters of ABNT NBR 6118, the maximum transverse reinforcement ratio would be about $1.2 \%$ in this situation(see Figure 6 ). Fur-

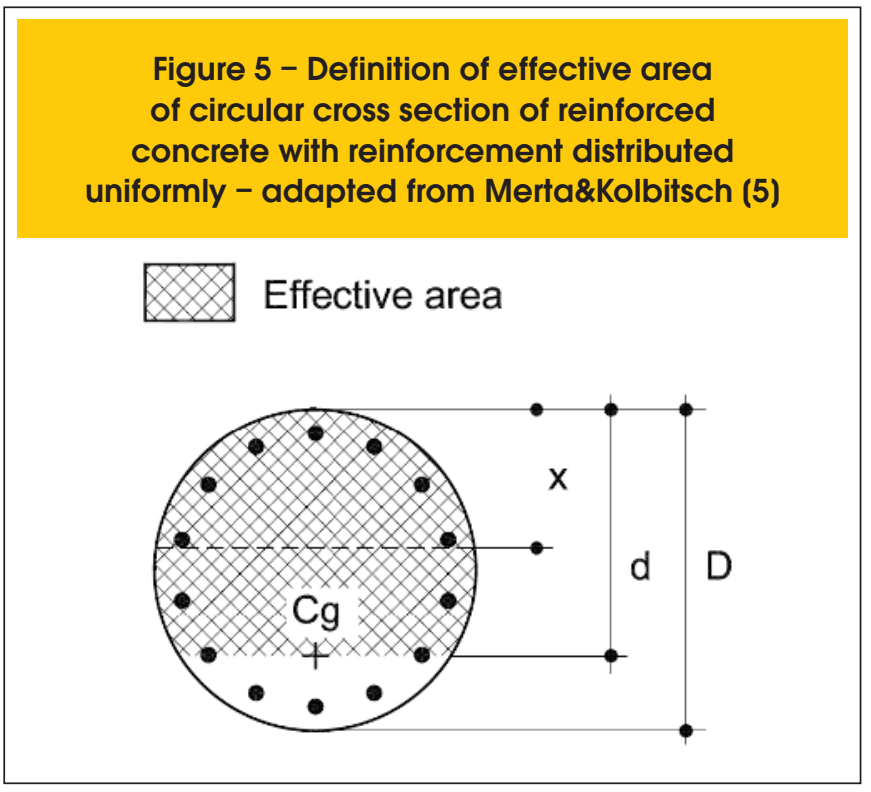

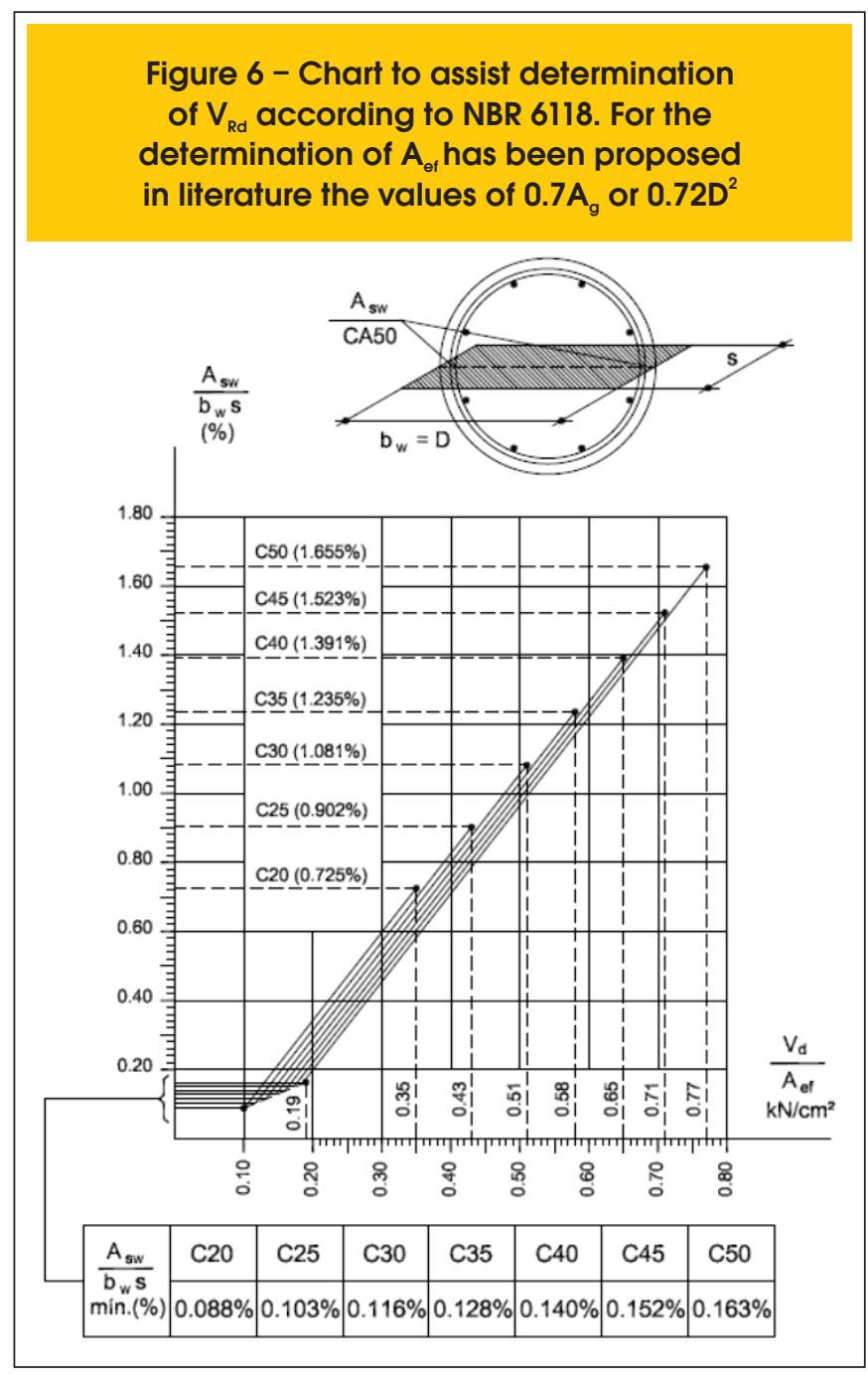

ther, it could be said that tests indicates that, in a beam of circular section, confinement caused by circular stirrups could increase the crushing strength of the compressed struts. Moreover, it can be stated that for the usual reinforcement rates the determination of $V_{R d 2}$ with dimensions $b_{w}=D$ and $d=0.72 D$, suggested by the AASHTO (2007), could lead to reasonable values for usual beams.

\subsection{Calculation of $V_{c}$}

The determination of the parcel of shear force resisted by complementary mechanisms to the trussis quite complex. In order to compare the few available parameters, it will be applied the procedures proposed by Merta [4] to the tests of Jensen et al [2]. According to [4], the value of $V_{c}$ could be estimated from:

$$
V_{c}=\left[3.7 \rho_{l}+0.18\right] \times \mathrm{k} \times \sqrt{f_{c}^{\prime}} \times 0.7 A_{g}
$$


Applying to the beams tested that did not have stirrups and had $2.56 \%$ of the longitudinal reinforcement, is obtained:

$V_{c}=3.7 \times 0.0256+0.18 \times 1.00 \times \sqrt{31.7} \times 0.7 \times 0.0491 \mathrm{~m}^{2}=0.053 \mathrm{MN}=53 \mathrm{kN}$

According to NBR 6118, the value of $V_{c}$ is function only of the tensile strength of concrete. The standard recommends that one adopt the lower value of tensile strength. In the case of the test beams the value of " $f_{\text {ctk,inf }}$ " could be estimated based on the average value of compressive strength presented $\left(f_{c}=31.7 \mathrm{MPa}\right)$, resulting in $f_{\text {ctk, inf }}=0.21 \mathrm{kN} / \mathrm{cm}^{2}$. Applying to the data of the problem and adopting $b_{w}=D$ and $d=0.72 D$, as recommended by AASHTO(2007) will find the next value of $V_{c}$.

$$
\mathrm{V}_{\mathrm{c}}=0.6 \times 0.21 \times 25 \times 0.72 \times 25=57 \mathrm{kN}
$$

Finally, by applying the concept of effective area with the expression of NBR 6118 , one obtains:

$$
\mathrm{V}_{\mathrm{c}}=0.6 \times 0.21 \times 0.7 \times \frac{\pi \times 25^{2}}{4}=43.29 \mathrm{kN}
$$

In tests, the value of the shear force resistance to the beams without stirrups varied between $70 \mathrm{kN}$ and $117 \mathrm{kN}$, all of which had longitudinal reinforcement rate composed by bars distributed along the perimeter, uniformly, of $2.56 \%$. Therefore, the values obtained in tests with some clearance exceed the predictions of the standard and Merta's [4] model. The two predictions reach values very close. However, considering that the value of $V_{c}$ is estimated as the product of a tension-resistant ban area, it is observed that these magnitudes as sumevery different values, as:

- The "ultimate stress" is 1.55MPain the expression of Merta [4] and 1.26M Pain the expression of NBR 6118;

- The "resisting area" is $344 \mathrm{~cm}^{2}$ on the expression of Merta [4] and was used with a value of $450 \mathrm{~cm}^{2}$ for application on the expression of NBR 6118;

- The products are close: $0.155 \times 344 \sim 0.126 \times 450=53 \mathrm{kN}$ a $57 \mathrm{kN}$. If the value of $V_{c}$ would be estimated as the one corresponding to the formation of the first shear crack, considering Stage I, it would result according to[10] and adopting $v=0.2$ for the concrete:

- $\zeta_{\text {máx }}=1.42(\mathrm{~V} / \mathrm{A})=0.21 \mathrm{kN} / \mathrm{cm}^{2}$, soon $\mathrm{V}=72.5 \mathrm{kN}$.

In the test, we obtained $\mathrm{V}$ between $70 \mathrm{kN}$ and $117 \mathrm{kN}$, which shows some dispersion in the results, with an average of $83.75 \mathrm{kN}$. Discarding the value of $\mathrm{V}=117 \mathrm{kN}$ the average changes to $72.7 \mathrm{kN}$.

\subsection{Calculation of $V_{s w}$}

For calculation of $\mathrm{V}_{\mathrm{sw}}$, part of the shear force resisted by the transverse reinforcement, the model proposed by Merta [4], is quite complex, because it considers the geometry of the circular stirrups properly. The model consists in determining the vertical com-

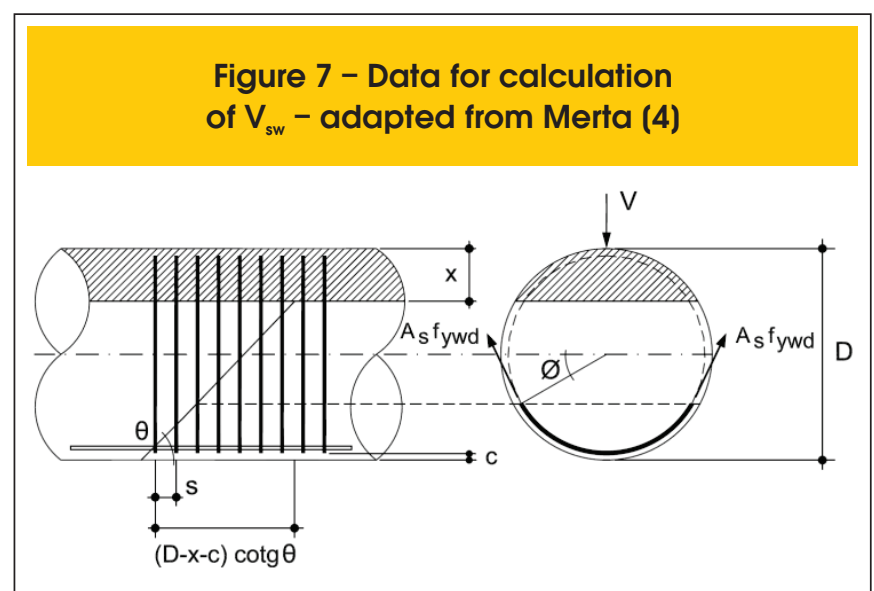

ponent of forces resulting from $\left(A_{s} f_{y w}\right)$ in each stirrup that crosses the cracks hear (Figure 7). Therefore, one should define how many stirrups there are at a distance $(\mathbf{D}-\mathbf{x}-\mathbf{c}) \operatorname{cotg} \theta$, where $\mathbf{D}$ is the diameter of the cross section $\mathbf{x}$ is the neutral axis position in cross section, $\mathbf{c}$ the overlay of reinforcement and $\theta$ the angle that the crack makes with the longitudinal axis of the beam. The mechanical model is to imagine that the stirrups crossing the crack will be mobilized, after cracking, considering the condition of ultimate resistance, which reaches the yield stress $\left(f_{\text {ywd }}\right)$.Compared to rectangular section, circular stirrups would be less efficient. Take, for example, a section with stirrups with a diameter of $10 \mathrm{~mm}$ spaced $10 \mathrm{~cm}$. If the beam section is rectangular, with $\mathrm{d}=60 \mathrm{~cm}$, the value of $\mathrm{V}_{\mathrm{sw}}$ provided, for example, by NBR6118,would be:

$$
V_{s w}=0.9 \times 60 \times \frac{2 x 0.8}{10} \times f_{y w d}=8.64 f_{y w d}
$$

Taking a circular section with a diameter " $D$ " $=60 / 0.72=83.33 \mathrm{~cm}$, so that it has the same effective height "d" of the rectangular section above, and considering covering " $c$ " $=3 \mathrm{~cm}$ and that the neutral axis position is $0.3 D=25 \mathrm{~cm}$, it would result $(\mathbf{D}-\mathbf{x}-\mathbf{c}) \operatorname{cotg} \theta$, with value of $55.33 \mathrm{~cm}$, in case of $\theta=45^{\circ}$ - as indicated in Model I of NBR 6118 . There would be 5 stirrupsacross the crack, as illustrated in Figure 8. Determining the vertical component of the forces at each stirrup, as shown in Figure 8, results find the value of $7.16 f_{y w d}-$ i.e., $17 \%$ less than that of a rectangular section with the same effective height. Merta [4] proposes the following expression to calculate this portion:

$$
\mathrm{V}_{\mathrm{sw}, 1}=1.8 \times \mathrm{n}_{\mathrm{t}} \times \mathrm{A}_{\mathrm{sw}} \mathrm{f}_{\mathrm{yw}}
$$

\section{where}

$$
\mathrm{n}_{\mathrm{t}}=\frac{(\mathrm{D}-\mathrm{x}-\mathrm{c})}{\mathrm{s}} \operatorname{cotg}(\theta)
$$




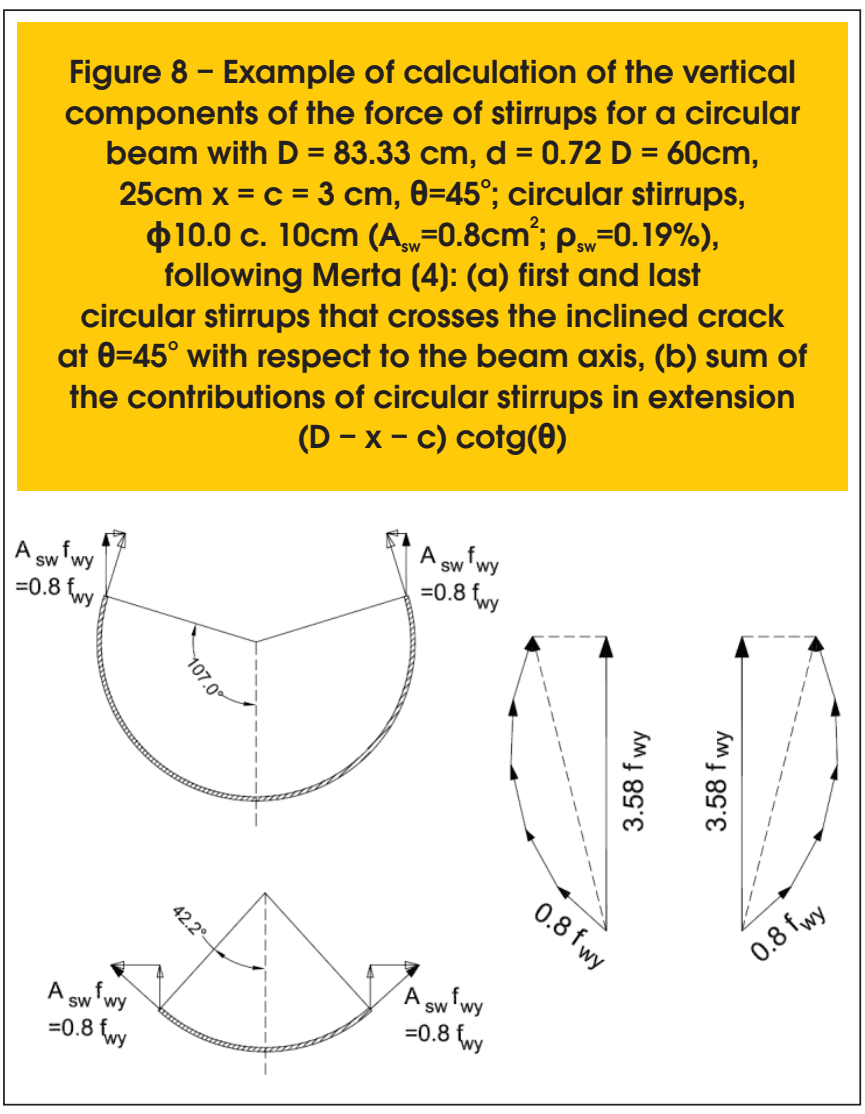

$n_{t}$ is the total number of stirrups that cross the crack, $D$ the diameter of the cross section, $\mathbf{x}$ the neutral axis position in cross section, $\mathbf{c}$ the covering of the reinforcement, $\mathbf{s}$ the spacing of the stirrups, $\theta$ the inclination angle of the crack with respect to the beam axis and $\mathbf{A}_{\text {sw }}$ the cross-sectional area of one circular stirrup. Applying the above expression, with $n_{t}=5$, we obtain $7.2 f_{\text {ywd }}$, i.e., practically the same value previously calculated.

Therefore, the circular stirrups are less efficient than the vertical stirrups usually employed in rectangular beams.

But beyond this resistant portion, Merta[4] suggests that there is another portion of contribution coming from the reinforcement formed by circular stirrups. This portion could be explained as being formed by the vertical components of the normal forces that arise in the region of adhesion of the circular stirrups adjacent to the crack-would be vertical components of forces due to the change in direction of the stirrup, determined using the formula of Coulomb for friction in pulleys for coefficient of friction with steel -concrete, $\mu=1.5$. In such a vertical stirrup this component does not exist, because the adhesion tensions would not have such vertical components. Merta [4], presents the deduction and proposes the following expression for determining such a parcel:

$$
\mathrm{V}_{\mathrm{sw}, 2}=\mathrm{A}_{\mathrm{sw}} \mathrm{f}_{\mathrm{yw}} \times\left(\lambda \cdot \mathrm{n}_{\mathrm{d}}+1\right)
$$

where

$$
n_{d}=\operatorname{INT}\left[\frac{\left(\frac{D}{2}-c\right)}{s} \operatorname{cotg}(\theta)\right]
$$

and $\lambda=0.53, n_{d}$ the number of stirrups crossing the crackup to half the height of the section and the other terms as the previous expressions. Applying in this particular case comes to $\mathrm{n}_{\mathrm{d}}=3$ and $\mathrm{V}_{\mathrm{sw}, 2}=2.072 \mathrm{f}_{\mathrm{ywd}}$ That is, the part resulting from deviation forces would be about $29 \%$ of the first parcel previously calculated.

\subsection{Calculation of $V_{R d 3}$}

The shear strength related to the concrete failure by diagonal tensile stresses, $V_{R d 3}$, would be obtained by the sum of $V_{c}$ and $V_{s w}$. Taking four samples of the tests of Jensen et al[2] which have not exhausted the capacity of the compressed struts, values can be compared, presented in Table 1. It is observed that the test results are always superior to those obtained with the expressions of Merta [4] and NBR 6118, using in the latter $b_{w}=D$ and $d=0.72 D$.

\section{Results and discussion}

The numerical results obtained with the expressions used in previous sections suggest that the determination of the resistant capacity of reinforced concrete elements with circular section is a subject that requires further experimental studies so that they can propose suitable expressions for use in projects of these elements. The numerical attempts made in order to determine the part of shear force resisted by complementary mechanisms to truss used two approaches: the concept of effective area proposed by Li [3] and Merta

\begin{tabular}{|c|c|c|c|c|c|c|}
\hline Exemplar & $A_{s w}$ & $\rho_{\mathrm{sw}}=\mathrm{A}_{\mathrm{sw}} /(\mathrm{Ds})$ & $f_{v w}(M P a)$ & Tests (2) & NBR 6118(*) & Merta (4) \\
\hline SDU5 & Ф8 c. 10 & $0.4 \%$ & 573 & 239 & 151.7 & 181.7 \\
\hline SDU6 & $\Phi 10$ c. 10 & $0.64 \%$ & 584 & 299 & 205.2 & 246.4 \\
\hline SDU8 & $2 \Phi 8$ c. 10 & $0.8 \%$ & 573 & 331 & 246.9 & 282.4 \\
\hline SDU7 & Ф12.5 c. 10 & $1 \%$ & 587 & 374 & 293.2 & 353.0 \\
\hline \multicolumn{7}{|c|}{ (*)With the proposed adjustments. } \\
\hline
\end{tabular}

Table 1 - Comparison of shear resistance value in $\mathrm{kN}$ - circular section, $\mathrm{D}=25 \mathrm{~cm} ; \mathrm{f}_{\mathrm{c}}=31.7 \mathrm{MPa}$ 
[4] and the concept of effective height equivalent submitted by the AASHTO as Jensen et al. [2].The differences found with experimental values were significant. On the other hand, comparing that portion to the shear force that would cause the first shear crack there was obtained nearest results from Jensen[2] testing, even though this cannot be confirmed due to the small number of experimental results available in the literature. The determination of the portion resisted by the reinforcement should take into account the lower efficiency of the circular stirrups, given that only the vertical component of force in the stirrup can resist the shear force. However, tests have shown that the simple consideration of this decomposition underestimates the resistance provided by the stirrups. The explanation of Merta [4] is related to the occurrence of deviation forces in the direction of tensile in the circular stirrups. In the analyzed example, such deviation forces accounted for $29 \%$ of the portion corresponding to the mobilization of stirrups crossing the shear crack.

Tests of Jensen et al [2] indicate that circular stirrups with heavy rates of reinforcement significantly increase the capacity of compressed strut which can be associated with the concrete confinement provided by circular stirrups. Perhaps these confinement effects has also influence on complementary mechanisms to truss and are responsible for the ultimate shear values of tests analyzed had always exceeded the theoretical estimates. In papers consulted, such as[2] and [4], it is reported the difficulty of measuring the deformation of transverse reinforcement, by relating such difficulty to the fact that the largest deformations would be located in the region of shear crack whose position is not known a prior which complicates the instrumentation of the stirrups.

It is also important to emphasize that in all tests analyzed the transverse reinforcement was constituted exclusively of circular stirrups, although in some projects there are situations in which the circular stirrups are supplemented with vertical branches.

\section{Conclusions}

After analyzing the tests results of reinforced concrete elements with circular cross section as well as the several theoretical contributions in literature, in order to verify the suitability of the expressions ofltem7.4 of the Brazilian standardABNTNBR6118 (2004), we present the following conclusions:

- The difficulty in defining the values of $b_{w}$ and $d$ for circular cross section has been approached in two ways, which are, the concept of effective area and the adoption of $b_{w}=D$ and $d=0.72 D$, and the latter approach leads to slightly better results than the experimental results analyzed.

- Determining $V_{\mathrm{Rd} 2}$, the value of the shear force corresponding to the concrete failure by diagonal compression, led to inferior results to those obtained in the tests analyzed, even adopting $b w=D$ and $d=0.72 D$, as recommended by international standards, which seems to be related to the confinement of the concrete produced by circular stirrups.

- Determining $\mathrm{V}_{\mathrm{Rd} 3}$, shear force corresponding to concrete failure by diagonal tension was also always lower than the values observed in the tests analyzed, even adopting $b_{w}=D$ and $d=0.72 D$, as recommended by international standards and considering the lower efficiency of the circular stirrups. The explanation must also be related to the confinement of the concrete produced by circular stirrups as well as the development of vertical components of adhesion forces resulting from the change in direction of the stirrups, as suggested by[4]. Even with these considerations, there were not obtained values close to those of tests analyzed.

Therefore, the use of $b_{w}=D$ and $d=0.72 D$, i.e., $A_{\text {ef }}=0.72 D^{2}$ as shown in [2], can lead to results for safety for the determination of $V_{\mathrm{Rd} 2}$ and $V_{c}$. The use of the expression $V_{s w}$ of the NBR 6118 with $d=0.72 \mathrm{D}$ also seems to lead to results in favor of safety in the determination of $V_{R d 3}$, despite not being made the reduction of the efficiency of the circular stirrups.

These conclusions are based only on the tests results analyzed and are referred to the condition of Ultimate Limit State. However, the authors practical experience with projects of circular cross-section beams subjected to high shear force syndicates that the use of such expressions has led to results suitable for service situations with apparently high safety factor.

\section{Bibliographic references}

[01] ASSOCIAÇÃO BRASILEIRA DE NORMAS TÉCNICAS. Projeto de estruturas de concreto. - NBR 6118, Rio de Janeiro, 2004

[02] JENSEN, U. G.; .HOANG, L. C.; JOERGENSEN, H. B.; FABRIN, L. S. Shear strength of heavily reinforced concrete members with circular cross section. Engineering Structures 32, N.3, (2010), 617-626.

[03] LI, VICTOR. A note on design of shear reinforcement for circular section. Technical Note TN-01. Centre for Research \& Professional Development (website: www.cprd-hk.com). February, 2009.

[04] MERTA, I. Shear strength model of reinforced concrete circular cross-section members. Structural Engineering Mechanics and Computation 3, A. Zingoni (ed.).(2007), Section 22, 493-494.

[05] MERTA, I.; KOLBITSCH, A. Shear area of reinforced concrete circular cross-section members. $31^{\text {st }}$ Conference on OUR WORLD IN CONCRETE \& STRUCTURES: 16-17 August 2006, Singapore.

[06] TURMO, J. RAMOS, G.APARICIO, A. C. Shear truss analogy for concrete members of solid and hollow circular cross section. Engineering Structures, 31 (2009), 455-465.

[07] ALMEIDA NETO, E. S.PEF-2306 - Tópicos de Mecânica dos Sólidos. Escola Politécnica da Universidade de São Paulo - Departamento de Engenharia de Estruturas e Geotécnica. São Paulo, 2011.

[08] MAFFEI, C. E. M.Memorial de cálculo da estrutura de contenção provisória para execução de vala a céu aberto. Documento interno da Maffei Engenharia. São Paulo, 2009.

[09] MAFFEI, C. E. M.Memorial de cálculo de vigas tubo utilizadas em obra de túnel rodoviário de baixa cobertura. Documento interno da Maffei Engenharia. São Paulo, 2011.

[10] TIMOSHENKO, S. P. GOODIER, J. N.Teoria da elasticidade. Guanabara Dois: Rio de Janeiro, 1980. p. 350.

[11] American Association of State Highway and Transportation Official. AASHTO LRFD Bridge design specifications. Fourth edition. 2007. 